\title{
"ANALISIS PENGARUH BRAND EQUITY DAN BRAND TRUST TERHADAP BUYING DECISION KAMERA CANON PADA KOMUNITAS PENCINTA FOTOGRAFI DI KOTA MALANG"
}

\author{
Tri Sugiarti Ramadhan \\ Fakultas Ekonomi \& Bisnis Universitas Islam Malang \\ Email : Tri.sugiartii95@Gmail.com
}

\begin{abstract}
Abstrak
Tujuan penelitian ini adalah 1) untuk mengetahui dan menganalisis pengaruh Kesadaran Merek, Kualitas yang dirasakan, Asosiasi Merek, dan Loyalitas Merek terhadap Kepercayaan Merek; 2) untuk mengetahui dan menganalisis pengaruh Kesadaran Merek, Kualitas yang dirasakan, Asosiasi Merek, dan Loyalitas Merek terhadap Keputusan Pembelian; 3) untuk mengetahui dan menganalisis pengaruh kepercayaan merek terhadap keputusan pembelian; 4) untuk mengetahui dan menganalisis pengaruh Kesadaran Merek, Kualitas yang dirasakan, Asosiasi Merek dan Loyalitas Merek terhadap Keputusan Pembelian melalui Kepercayaan Merek.

Jenis penelian ini adalah explanatory research dengan menggunakan pendekatan kuantitatif. Populasi dalam penelitian ini adalah pengguna kamera DSLR (Digital Single Lens Reflex) atau Mirrolless pada Komunitas Pecinta Fotografi di Kota Malang, Jawa Timur. Teknik pengambilan sampel dilakukan dengan purposive sampling dan didapatkan sampel sebanyak 65 responden. Dengan menggunakan metode analisis Path hasil penelitian menunjukan bahwa Kesadaran Merek, Kualitas yang dirasakan, Asosiasi Merek, Loyalitas Merek, dan Kepercayaan Merek berpengaruh signifikan terhadap Keputusan Pembelian.

Kata kunci : Kesadaran Merek, Kualitas yang dirasakan, Asosiasi Merek, Loyalitas Merek, Kepercayaan Merek, Keputusan Pembelian
\end{abstract}

\begin{abstract}
The purposes of this research are 1) to know and analyze the influence of Brand Awareness, Perceived Quality, Brand Association, and Brand Loyalty to Brand Trust; 2) to know and analyze the influence of Brand Awareness, Perceived Quality, Brand Association, and Brand Loyalty to Buying Decision; 3) to know and analyze the influence of Brand Trust on Buying Decision; 4) to know and analyze the influence of Brand Awareness, Perceived Quality, Brand Associations and Brand Loyalty to Buying Decision through Brand Trust.

This research is an explanatory research using quantitative approach. Population on this research are DSLR (Digital Single Lens Reflex) or Mirrolless camera users on Photography Lovers Community in Malang, East Java. The samples are taken by using purposive sampling and obtained the sample size of 65 respondents. Using Path analysis method the results showed that Brand Awareness, Perceived Quality, Brand Association, Brand Loyalty and Brand Trust has significant effect on Buying Decision.
\end{abstract}

Keyword : Brand Awareness, Perceived Quality, Brand Association, Brand Loyalty, Brand Trust, Buying Decision. 


\section{PENDAHULUAN}

Perkembangan fotografi sendiri sangat cepat, seperti penambahan megapixel yang mampu menghasilkan gambar jauh lebih baik. Disamping itu juga ada perbaikan sensor pada kamera. Secara singkat kamera saat ini lebih canggih dibanding dengan kamera beberapa tahun lalu. Fungsi kamera juga sudah meluas tidak hanya untuk keperluan pribadi, akan tetapi dapat dimanfaatkan dalam kegiatan pemantauan, penelitian. Serta berfungsi sebagai bagian dari gaya hidup seseorang.

Perusahaan semakin menyadari merek menjadi faktor penting dalam persaingan dan menjadi aset perusahaan yang bernilai (Kokasih et al., 2013). Merek dikatakan mempunyai ekuitas, dengan pertimbangan pelanggan terlebih dahulu akan mengenal atau hanya mendengar saja baik dari media maupun rekan (Andianti, dkk. 2012). Ekuitas merek memberikan nilai bagi konsumen yang bisa mempengaruhi rasa percaya diri dalam mengambil keputusan pembelian (Rofiq, dkk 2009).

Disisilain Kepercayaan konsumen terhadap merek juga merupakan alasan penting menentukan kamera yang akan digunakannya (Delgado: 2004). Oleh karena Ekuitas Merek dan Kepercayaan terhadap merek merupakan variabel penting yang mempengaruhi keputusan pembelian suatu kamera maka, penelitian ini dimaksudkan untuk menganalisis seberapa besar komunitas fotografi di Kota Malang. Alasan memilih komunitas fotografi di Kota Malang karena rata-rata komunitas tersebut menggunakan kamera DSLR (Digital Sigle Lens Reflex)/Mirrolles.

Berdasarkan latar belakang yang telah diuraikan sebelumnya maka penelitian ini diambil judul sebagai berikut: "Analisis pengaruh Brand Equity dan Brand Trust Terhadap Buying Decision Kamera Canon pada Komunitas Pencinta Fotografi Di Kota Malang". Berdasarkan uraian maka rumusan masalah tersebut dapat diajukan beberapa pertanyaan penelitian sebagai berikut:

1. Apakah terdapat pengaruh Ekuitas Merek (Kesadaran Merek, Kualitas yang dirasakan, Asosiasi Merek dan Loyalitas Merek) terhadap Kepercayaan Merek.

2. Apakah terdapaat pengaruh Ekuitas Merek (Kesadaran Merek, Kualitas yang dirasakan, Asosiasi Merek dan Loyalitas merek) terhadap Keputusan Pembelian.

3. Apakah terdapat pengaruh Kepercayaan Merek terhadap Keputusan Pembelian.

4. Apakah terdapat pengaruh Ekuitas Merek (Kesadaran Merek, Kualitas yang dirasakan, Asosiasi Merek dan Loyalitas Merek) terhadap Keputusan pembelian melalui Kepercayaan Merek.

\section{KAJIAN TEORI}

Widhiarta \& Wardana (2015) Analisis Pengaruh ekuitas merek Terhadap Keputusan Pembelian Iphone di Denpasar, Barus (2015) Analisis Pengaruh ekuitas merek Terhadap Keputusan Pembelian smartphone blackberry" Susanto, Waluyo \& Santoso (2017) Analisis Pengaruh ekuitas merek Terhadap Keputusan Pembelian Smartphone Samsung, Siali, Jiayi, Shakur and Ya'kob (2016) Relationship Between Brand Equity And 
Consumer Purchase Decision: A Case Of An International Brand Of Footwear.

Pengertian ekuitas merek (brand equity) adalah seperangkat asosiasi dan perilaku yang dimilki oleh pelanggan merek, anggota saluran distribusi , dan perusahaan yang memungkinkan suatu merek mendapatkan kekuatan, daya tahan, dan keunggulan yang membedakan dengan para pesaing (David Aaker, 2013:204).

Kesadaran merek adalah pengakuan dan pengingatan dari sebuah merek dan pembedaan dari merek yang lain yang ada dilapangan. jadi kesadaran merek adalah kemampuan seseorang untuk mengingat suatu merek dan menjadikannya berbeda dengan merek lainya.

Menurut Zheithaml dalam muafi dan effendi (2001) kualitas yang dirasakan diartikan sebagai yang dirasakan pelanggan terhadap keseluruhan kualitas atau keunggulan suatu produk atau jasa layanan berkenaan dengan maksud yang diharapkan.

Menurut Aaker (1991) adalah segala hal yang berkaitan dengan ingatan mengenai merek atau dengan katalain segala kesan yang muncul dibenak seseorang terkait dengan ingatanya mengenai suatu merek. Aaker (1997) mendefinisikan loyalitas merek adalah suatu ukuran keterkaitan seorang pelanggan, pada sebuah merek.

Kepercayaan merek didefinisikan sebagai sifat positif seseorang konsumen terhadap suatu merek, sehingga konsumen memiliki keinginan kuat untuk membeli ulang merek yang sama pada saat sekarang maupun masa yang akan datang. Menurut chayadi (2006:55) kepercayaan pelanggan pada merek didefinisikan sebagai keinginan pelanggan untuk bersandar pada sebuah merek dengan resiko-resiko yang dihadapi karena ekspetasi terhadap mereka akan menyebabkan hasil yang positif.

Keputusan pembelian menurut Helga Drumond (2003:68) adalah mendefinisikan semua pilihan yang mungkin untuk memecahkan persoalan itu dan menilai pilihan-pilihan secara sitematis dan obyektif serta sasaransasarannya yang menentukan keuntungan serta keinginannya masingmasing. Sedangkan definisi keputusan pembelian menurut nugroho (2003:38) adalah proses penitegrasian yang mengkombinasi sikap pengetahuan untuk mengevaluasi dua atau lebih perilaku alternatif, dan memilih salah satu diantaranya.

Kerangka Konseptual

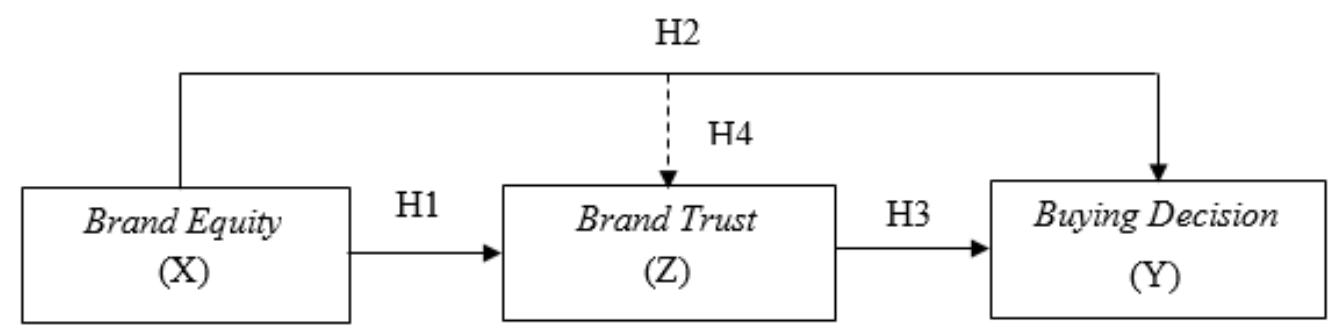

Berdasarkan perumusan masalah, tinjauan pustaka dan tinjauan penelitian, dapat ditarik hipotesis atau kesimpulan sementara pada penelitian ini, yaitu: H1 : Kesadaran Merek, Kualitas yang dirasakan, Asosiasi Merek, dan Loyalitas berpengaruh terhadap Kepercayaan Merek. 
H2 : Kesadaran Merek, Kualitas yang dirasakan, Asosiasi Merek, dan Loyalitas berpengaruh terhadap Keputusan Pembelian. H3 : Kepercayaan Merek berpengaruh terhadap Keputusan Pembelian.

H4 : Kesadaran Merek, Kualitas yang dirasakan, Asosiasi Merek dan Loyalitas Merek berpengaruh terhadap Keputusan Pembelian Melalui Kepercayaan Merek.

\section{METODE PENELITIAN}

Penelitian ini menggunakan pendekatan kuantitatif. Penelitian ini dilakukan di wilayah Kota Malang. Khususnya kepada komunitas-komunitas pecinta fotografi yang menggunakan kamera DSLR atau Mirrolless. Waktu penelitian ini dilakukan mulai bulan Juli 2017 - November 2017. Sedangkan waktu turun lapang dilakukan satu bulan selama januari 2018. Populasi dalam penelitian ini adalah seluruh pengguna kamera DSLR dan Mirrolless pada komunitas fotografi di Kota Malang yang berjumlah 180 orang. Sugiyono (2013:124) Menentukan sampel yang diambil dari populasi penelitian menggunakan rumus dalam Slovin yaitu, sebagai berikut:

Rumus slovin

Keterangan:

$$
\mathrm{n}=\frac{N}{1+N(e) 2}
$$

$\mathrm{n}$ : Ukuran sampel

$\mathrm{N}$ : Ukuran populasi

e: Persen Kelonggaran ketidak telitian pada penelitian ini derajat kesalahan sampel yang diinginkan sebesar $10 \%$ sehingga perhitungan sampelnya menjadi.

$$
n=\frac{180}{1+180(10 \%) 2}
$$

Berdasarkan rumus diatas maka diperoleh responden 64,285 jika dibulatkan maka menjadi 65 responden.

Berdasarkan pokok permasalahan dan rumusan hipotesis, variabel penelitian dikelompokan menjadi 6 variabel

a. Kesadaran Merek (X1), Kualitas yang dirasakan (X2), Asosiasi Merek (X3), Loyalitas Merek (X4) sebagai variabel Bebas (Independent).

b. Kepercayaan Merek (Y1), Keputusan Pembelian (Y2), Sebagai variabel terikat (Dependent).

Sementara definisi operasional variabel merupakan suatu definisi yang diberikan kepada suatu variabel dengan memberi arti atau menspesifikkan kegiatan atau membenarkan suatu operasional yang diperlukan untuk mengukur variabel tersebut (Sugiyono, 2001).

Berdasarkan pokok permasalhan dan rumusan hipotesis, variabel penelitian dikelompokan menjadi 6 variabel Berkaitan dengan penelitian ini, variabel penelitian yang terdiri dari variabel dependen dan variabel 
independen diuraikan sebagai berikut : Dalam penelitian ini terdapat dua variabel, yaitu variabel independen dan variabel dependen

Data yang digunakan dalam penelitian ini adalah data primer dan data sekunder. Data primer dan data sekunder. Untuk menguji pengaruh variabel intervening, digunakan metode analisis jalur."Analisis jalur ( $P$ ath Analysis) merupakan pengembangan dari analisis regresi, sehingga analisis regresi dapat dikatakan sebagai bentuk khusus dari analisis jalur (regresion is special case of path analysis)" Sugiyono (2011:297)."Analisis jalur digunakan untuk melukiskan dan menguji model hubungan antar variabel yang berbentuk sebab akibat (bukan bentuk hubungan interaktif atau reciprocal).

Uji validitas adalah untuk mengetahui tingkat kevalidan dari instrument kuesioner yang digunakan dalam pengumpulan data. Uji validitas ini dilakukan untuk mengetahui apakah item-item yang tersaji dalam koesioner benar-benar mampu mengungkapkan dengan pasti apa yang akan diteliti.

Reliabilitas menyangkut alat ukur. Suatu alat ukur disebut mempunyai reabilitas tinggi atau dapat dipercaya, jika alat ukur mantap, dapat di andalkan (dependability) dan dapat diramalkan (predictability), serta konsisten dalam mengukur apa yang ingin diukur. Teknik uji reliabilitas menggunakan koefisien alpha cronbach pada taraf signifikan $5 \%$.

Uji Normalitas dilakukan untuk mengetahui apakah tiap-tiap variabel berdistribusi normal atau tidak maka, bila nilai probabilitas atau signifikan < 0,005 , distribusi adalah tidak normal dan sebaliknya jika besarnya signifikan $>0,005$ maka distribusi normal di lihat dari tabel Kolmogorov smirnov ini dapat dilihat dari nilai dari taraf signifikan >0,005 sulaiman (2004:108).

Multikolinearitas menunjukan adanya lebih dari satu hubungan linier yang sempurna. Hal tersebut seperti yang telah dikemukakan oleh santoso (2002:203) bahwa tujuan uji multikolinearitaas adalah untuk menguji apakah pada model regresi ditemukan adannya korelasi atar variabel independent.

Uji Heterokedasitas bertujuan menguji apakah dalam model regresi terjadi ketidaksamaan varians dari residual satu pengamatan ke pengamatan yang lain. Jika varians dari residual satu pengamatan ke pengamatan lain tetap, maka disebut homoskedasitas dan jika berbeda disebut heterokedasitas. Model regresi yang baik adalah homoskedasitas atau tidak terjadi heterokedasitas. Uji heterokedasitas menggunakan Glejser Test, yaitu pengujian dengan cara meregresikan nialai absolut residual terhadap variabel independen.

Ketepatan fungsi regresi sampel dalam menaksir nilai aktual dapat diukur dari goodness of fit nya. Secara statistik, setidaknya ini dapat diukur dari nilai koefisien determinasi, nilai statistik $F$ dan nilai statistik $t$. Perhitungan statistik disebut signifikan secara statistik apabila nilai uji statistiknya berada dalam nilai daerah kritis (daerah dimana $\mathrm{HO}$ ditolak). sebaliknya disebut tidak signifikan bila nilai uji statistiknya berada dalam daerah dimana $\mathrm{HO}$ diterima.

Uji parsial (uji t) digunakan untuk mengetahui apakah model regresi variabel independen serta parsial berpengaruh signifikan terhadap variabel 
dependen (Priyono, 2015). Uji t pada dasarnya untuk menunjukkan seberapa besar pengaruh suatu variabel independen terhadap variabel dependen.

Pengujian ini digunakan untuk mengetahui tingkat kepercayan yang terbaik dalam analisis regresi linier dalam hal ini ditunjukkan oleh besarnya koefisien determinasi. Koefisien determinasi $\left(R^{2}\right)$ pada intinya mengukur seberapa jauh kemampuan model dalam merangkai variasi variabel independen.

\section{HASIL ANALISIS DATA}

Responden yang menjadi subjek pada penelitian ini adalah pengguna camera DRSLR atau Mirrolless pada komunitas pecinta fotografi di kota malang. Berdasarkan hasil penelitian yang telah dilakukan terhadap 65 pengguna camera DRSLR atau Mirrolless pada komunitas pecinta fotografi di kota malang.

Dari hasil data yang diambil, 65 orang yang menjadi sampel pada penelitian ini, 60 orang $(92,3 \%)$ diantaranya adalah laki-laki dan 5 orang $(7,7 \%)$ lainnya adalah perempuan. Berdasarkan data yang diambil, dari 65 orang yang menjadi sampel pada penelitian ini, 37 orang $(56,9 \%)$ diantaranya berusia antara $21-25$ tahun, 12 orang $(18,5 \%)$ berusia kurang dari 20 tahun, 12 orang (18,5\%) berusia antara 26-30 tahun, 12 orang $(18,5 \%)$ berusia antara $36-50$ tahun dan 4 orang $(6,2 \%)$ lainnya berusia antara 31-35 tahun. 65 orang yang menjadi sampel pada penelitian ini, 50 orang $(76,9 \%)$ diantaranya memiliki kamera sebanyak 1 buah, 11 orang $(16,9 \%)$ memiliki kamera sebanyak 2 buah dan 4 orang $(6,2 \%)$ lainnya memiliki kamera sebanyak 3 buah. 65 orang yang menjadi sampel pada penelitian ini, 48 orang $(73,8 \%)$ diantaranya adalah mahasiswa, 7 orang $(10,8 \%)$ adalah seorang wiraswasta, 6 orang $(9,2 \%)$ adalah pegawai swasta dan 4 orang $(6,2 \%)$ lainnya adalah pegawai negeri.

Variabel Kesadaran Merek (X1) memiliki 3 item pernyataan. Sebagian besar responden menjawab setuju pada item semua pertanyaan yang diajukan. Rata-rata tertinggi terdapat pada item pertanyaan no 1 yaitu saya dapat mengingat dengan cepat logo atau symbol dari kamera Canon, sedangkan rata-rata terendah terdapat pada item no 3 yaitu saya dapat langsung mengenali kamera merek Canon dengan hanya melihat model atau varian atau tipenya.

Variabel Kualitas yang dirasakan (X2) memiliki 5 item pernyataan. Sebagian besar responden menjawab setuju pada semua item pertanyaan yang diajukan. Rata-rata tertinggi terdapat pada item pertanyaan no 4 yaitu kamera merek Canon tidak mudah rusak, sedangkan rata-rata terendah terdapat pada item no 2 yaitu kamera merek Canon adalah kamera yang berkualitas.

Variabel Asosiasi Merek (X3) memiliki 3 item pernyataan. Sebagian besar responden menjawab setuju pada semua item pertanyaan yang diajukan. Rata-rata tertinggi terdapat pada item pertanyaan no 3 yaitu kamera merek Canon memberikan manfaat bagi saya seorang fotografer, 
sedangkan rata-rata terendah terdapat pada item no 2 yaitu kamera merek Canon memiliki fitur yang canggih.

Variabel Loyalitas Merek (X3) memiliki 4 item pernyataan. Sebagian besar responden menjawab setuju pada semua item pertanyaan yang diajukan. Rata-rata tertinggi terdapat pada item pertanyaan no 4 yaitu saya akan tetap membeli kamera Canon meski harganya naik dan lebih tinggi dari pada kamera merek lainnya yang sejenis, sedangkan rata-rata terendah terdapat pada item no 3 yaitu saya tidak akan terpengaruh pada promosi merek lain.

Variabel Kepercayaan Merek (Z) memiliki 5 item pernyataan. Sebagian besar responden menjawab setuju pada semua item pertanyaan yang diajukan. Rata-rata tertinggi terdapat pada item pertanyaan no 1 yaitu kamera Canon dapat saya percaya, sedangkan rata-rata terendah terdapat pada item no 2 kamera Canon dapat saya andalkan dan item no 4 yaitu kamera Canon sesuai dengan harapan saya.

Variabel Keputusan Pembelian (Y) memiliki 3 item pernyataan. Sebagian besar responden menjawab setuju pada item pertanyaan no 1 yaitu saya yakin membeli kamera merek Canon dan item no 3 yaitu saya lebih memilih kamera merek Canon dibanding kamera merek lain. Sedangkan pada item pertanyaan no 2, saya membeli kamera merek Canon berdasarkan informasi yang saya miliki sebagian besar responden menjawab netral. Rata-rata tertinggi terdapat pada item pertanyaan no 1 yaitu saya yakin membeli kamera merek Canon, sedangkan rata-rata terendah terdapat pada item no 2 saya membeli kamera merek Canon berdasarkan informasi yang saya miliki.

Berdasarkan tabel 4.11 diketahui bahwa semua item pertanyaan pada masing-masing variabel memiliki $r_{\text {hitung }}>r_{\text {tabel }}(0,244)$ atau nilai signifikansinya lebih kecil dari taraf nyata $5 \%$ sehingga disimpulkan itemitem pertanyaan tersebut valid dan dapat digunakan untuk penelitian selanjutnya.

Tabel 4.12

Hasil Uji Reliabilitas

\begin{tabular}{|l|l|l|}
\hline Variabel & Cronbach's Alpha & N of Items \\
\hline Kesadaran Merek & 0,733 & 3 \\
Kualitas yang dirasakan & 0,693 & 5 \\
Asosiasi Merek & 0,748 & 3 \\
Loyalitas Merek & 0,733 & 4 \\
Kepercayaan Merek & 0,907 & 5 \\
Keputusan Pembelian & 0,801 & 3 \\
\hline
\end{tabular}

\section{Sumber Diolah, 2018}

Instrumen dikatakan reliabel, jika nilai alpha crobach sama dengan atau di atas 0,6. Berdasarkan tabel di atas diketahui bahwa nilai alpha cronbach yang diperoleh pada masing-masing variabel lebih besar dari 0,6 
sehingga disimpulkan bahwa item-item pertanyaan yang valid tersebut telah reliable dan dapat digunakan untuk penelitian selanjutnya.

Tabel 4.13

Hasil Uji Normalitas Variabel Penelitian

\begin{tabular}{|c|c|c|c|}
\hline Variabel Penelitian & $\begin{array}{l}\text { Kolmogorov- } \\
\text { Smirnov Z }\end{array}$ & Sig. & Keterangan \\
\hline Kesadaran Merek (X1) & 1,049 & 0,221 & $\begin{array}{l}\text { Berdistribusi } \\
\text { Normal }\end{array}$ \\
\hline Perceived Quality (X2) & 1,190 & 0,118 & $\begin{array}{l}\text { Berdistribusi } \\
\text { Normal }\end{array}$ \\
\hline Asosiasi Merek (X3) & 1,056 & 0,214 & $\begin{array}{l}\text { Berdistribusi } \\
\text { Normal }\end{array}$ \\
\hline Loyalitas Merek (X4) & 1,160 & 0,136 & $\begin{array}{l}\text { Berdistribusi } \\
\text { Normal }\end{array}$ \\
\hline Kepercayaan Merek (Z) & 1,121 & 0,162 & $\begin{array}{l}\text { Berdistribusi } \\
\text { Normal }\end{array}$ \\
\hline $\begin{array}{l}\text { Keputusan Pembelian } \\
\text { (Y) }\end{array}$ & 1,077 & 0,197 & $\begin{array}{l}\text { Berdistribusi } \\
\text { Normal }\end{array}$ \\
\hline
\end{tabular}

Sumber Diolah, 2018

Berdasarkan hasil pengujian normalitas pada tabel di atas diketahui bahwa nilai signifikansi pada masing-masing variabel penelitian lebih besar dari taraf nyata 5\% sehingga disimpulkan asumsi normalitas terpenuhi.

Hasil pengujian disajikan sebagai berikut:

Tabel 4.14

Hasil Uji Normalitas Residual Regresi

\begin{tabular}{|l|l|l|l|}
\hline $\begin{array}{l}\text { Persamaan } \\
\text { Struktural }\end{array}$ & $\begin{array}{l}\text { Kolmogorov- } \\
\text { Smirnov Z }\end{array}$ & $\begin{array}{l}\text { Nilai } \\
\text { sig. }\end{array}$ & Keterangan \\
\hline$X 1, X 2, X 3, X 4 \rightarrow Z$ & 0,652 & 0,788 & $\begin{array}{l}\text { Berdistribusi } \\
\text { Normal }\end{array}$ \\
\hline $\begin{array}{l}X 1, X 2, X 3, X 4 \text { dan } \\
Z \rightarrow Y\end{array}$ & 0,554 & 0,919 & $\begin{array}{l}\text { Berdistribusi } \\
\text { Normal }\end{array}$ \\
\hline
\end{tabular}

\section{Sumber Diolah, 2018}

Berdasarkan hasil pengujian normalitas pada tabel di atas diketahui bahwa nilai signifikansi residual regresi yang terbentuk pada persamaan structural 1 dan 2 lebih besar dari taraf nyata 5\% sehingga disimpulkan asumsi normalitas terpenuhi. 
Berikut adalah tabel pengaruh antar variabel dan persamaan jalur

Tabel 4.15

Pengaruh Antar Variabel

\begin{tabular}{|l|l|l|l|}
\hline \multirow{2}{*}{ Pengaruh } & \multicolumn{2}{|l|}{ Koefisien Jalur } & \multirow{2}{*}{$\mathbf{R}^{2}$} \\
\cline { 2 - 4 } & B & Beta & \\
\hline$X 1 \rightarrow Z$ & 0,827 & 0,354 & $20,9 \%$ \\
$X 2 \rightarrow Z$ & 0,376 & 0,223 & $13,2 \%$ \\
$X 3 \rightarrow Z$ & 0,519 & 0,224 & $13,2 \%$ \\
$X 4 \rightarrow Z$ & 0,540 & 0,279 & $16,5 \%$ \\
\hline Total & & & $63,8 \%$ \\
\hline$X 1 \rightarrow Y$ & 0,232 & 0,171 & $11,7 \%$ \\
$X 2 \rightarrow Y$ & 0,182 & 0,186 & $12,7 \%$ \\
$X 3 \rightarrow Y$ & 0,287 & 0,214 & $14,6 \%$ \\
$X 4 \rightarrow Y$ & 0,207 & 0,185 & $12,6 \%$ \\
$Z \rightarrow Y$ & 0,216 & 0,373 & $25,5 \%$ \\
\hline Total & \multicolumn{2}{|l}{} \\
\hline
\end{tabular}

Sumber Diolah, 2018

a. Pengaruh Kesadaran Merek, Kualitas yang dirasakan, Asosiasi Merek dan Loyalitas Merek terhadap Kepercayaan Merek.

Persamaan jalur yang terbentuk yaitu:

$Z=0,354 X 1+0,223 X 2+0,224 X 3+0,279 X 4$

b. Pengaruh Kesadaran Merek, Kualitas yang dirasakan, Asosiasi Merek, Loyalitas Merek dan Kepercayaan Merek terhadap Keputusan Pembelian.

Persamaan jalur yang terbentuk yaitu:

$$
Y=0,171 X 1+0,186 X 2+0,214 X 3+0,185 X 4+0,373 Z
$$


Gambar 4.1

\section{Uji Heterokedastisitas dengan Scatter Plot}

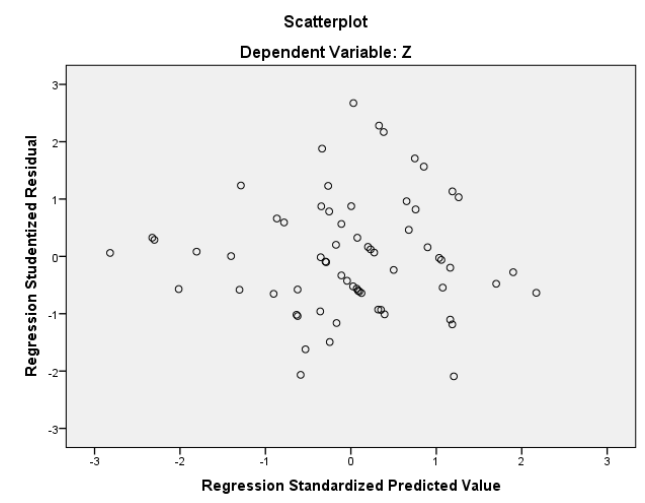

Scatterplot

Dependent Variable: $Y$

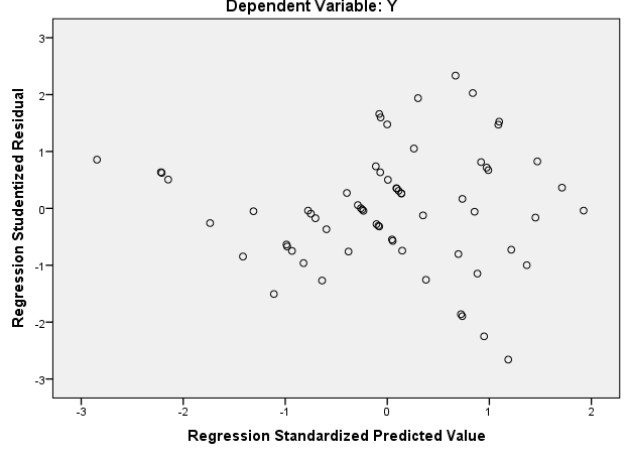

Hasil uji heterokedastisitas menggunakan scatter plot menunjukkan bahwa titik-titik menyebar secara acak dan tidak membentuk pola tertentu. Hal ini menunjukkan bahwa tidak terdapat indikasi adanya heterokedastisitas pada model yang diuji sehingga asumsi ini terpenuhi. Selain menggunakan metode grafik, pengujian asumsi heteroskedastisitas dapat dilakukan juga dengan metode pengujian statistik uji Glejser. Uji Glejser dilakukan dengan meregresikan variabel bebas terhadap nilai absolut residualnya. Apabila nilai sig. > 0,05 maka akan terjadi homoskedastisitas dan jika nilai sig. $<0,05$ maka akan terjadi heteroskedastisitas. Hasil uji Glejser dapat dilihat pada tabel berikut:

Tabel 4.16

Hasil Uji Glejser

\begin{tabular}{|c|c|c|}
\hline Variabel Bebas & Sig. & Keterangan \\
\hline \multicolumn{3}{|c|}{$\begin{array}{l}\text { Persamaan Struktural } \\
1\end{array}$} \\
\hline $\mathrm{X} 1$ & 0,869 & Tidak terjadi Heteroskedastisitas \\
\hline $\mathrm{X} 2$ & 0,084 & Tidak terjadi Heteroskedastisitas \\
\hline X3 & 0,437 & Tidak terjadi Heteroskedastisitas \\
\hline$X 4$ & 0,301 & Tidak terjadi Heteroskedastisitas \\
\hline
\end{tabular}




\begin{tabular}{|c|c|c|}
\hline Variabel Bebas & Sig. & Keterangan \\
\hline \multicolumn{3}{|c|}{$\begin{array}{l}\text { Persamaan Struktural } \\
2\end{array}$} \\
\hline $\mathrm{X} 1$ & 0,805 & Tidak terjadi Heteroskedastisitas \\
\hline $\mathrm{X} 2$ & 0,441 & Tidak terjadi Heteroskedastisitas \\
\hline X3 & 0,400 & Tidak terjadi Heteroskedastisitas \\
\hline X4 & 0,786 & Tidak terjadi Heteroskedastisitas \\
\hline Z & 0,112 & Tidak terjadi Heteroskedastisitas \\
\hline
\end{tabular}

Berdasarkan tabel diatas diketahui bahwa pada masing-masing variabel diperoleh nilai sig. > 0,05 maka disimpulkan tidak terjadi heteroskedastisitas. Atau dengan kata lain asumsi non-heteroskedastisitas telah terpenuhi.

Tabel 4.17

Hasil Uji Multikolinearitas

\begin{tabular}{|l|l|l|}
\hline Variabel bebas & Tolerance & VIF \\
\hline Persamaan Struktural 1 & & \\
X1 & 0,732 & 1,367 \\
X2 & 0,744 & 1,343 \\
X3 & 0,791 & 1,263 \\
X4 & 0,695 & 1,439 \\
\hline Persamaan Struktural 2 & & \\
X1 & 0,584 & 1,712 \\
X2 & 0,676 & 1,480 \\
\hline Variabel bebas & Tolerance & VIF \\
\hline X3 & 0,713 & 1,402 \\
X4 & 0,604 & 1,654 \\
Z & 0,362 & 2,761 \\
\hline
\end{tabular}

Sumber Diolah, 2018

Berdasarkan hasil analisis di atas, terlihat bahwa pada kedua model regresi nilai VIF $<10$ dan Tolerance $>0,1$ sehingga disimpulkan tidak terjadi gejala multikolinearitas dalam model regresi yang terbentuk. 
Tabel 4.18

Hasil Uji Linieritas

\begin{tabular}{|l|l|l|l|}
\hline Variabel independen & Variabel dependen & p-value & Keterangan \\
\hline X1 & & 0,000 & Berhubungan Linier \\
X2 & Z & 0,000 & Berhubungan Linier \\
X3 & & 0,000 & Berhubungan Linier \\
X4 & & 0,000 & Berhubungan Linier \\
\hline X1 & & 0,000 & Berhubungan Linier \\
X2 & Y & 0,000 & Berhubungan Linier \\
X3 & & 0,000 & Berhubungan Linier \\
X4 & & 0,000 & Berhubungan Linier \\
Z & & 0,000 & Berhubungan Linier \\
\hline
\end{tabular}

Sumber Diolah, 2018

Hasil uji linieritas menunjukkan p-value masing-masing hubungan lebih kecil dari alpha $5 \%(0,050)$ sehingga disimpulkan bahwa antar variabel tersebut terdapat hubungan yang linier atau dengan kata lain asumsi linieritas terpenuhi. Pada penelitian ini terdapat 9 pengaruh langsung dan 4 pengaruh tidak langsung dari analisis yang dilakukan. Berikut disajikan hasil pengujiannya.

Hipotesis kesadaran merek (X1), kualitas yang dirasakan (X2) asosiasi merek (X3) loyalitas Merek (X4) terhadap variabel Kepercayaan Merek (Z). adapun besarnnya nilai masing-masing berpengaruh dari variabel bebas terhadap variabel terikat dapat diketahui pada tabel berikut:

Tabel 4.19

Hasil Pengujian Hipotesis t

Pengaruh kesadaran merek (X1), kualitas yang dirasakan (X2) asosiasi merek (X3) terhadap variabel Kepercayaan Merek (Z)

\begin{tabular}{|l|l|l|l|}
\hline Variabel & t hitung & t tabel & Sig. \\
\cline { 1 - 2 } $\begin{array}{l}\text { X1 } \\
\text { (kesadaran Merek) }\end{array}$ & 3,894 & 2,001 &, 000 \\
\cline { 1 - 2 } $\begin{array}{l}\text { X2 } \\
\text { (Kualitas yang dirasakan) }\end{array}$ & 2,472 &, 016 \\
\cline { 1 - 2 } $\begin{array}{l}\text { X3 } \\
\text { (Asosiasi Merek) }\end{array}$ & 2,566 &, 013 \\
\cline { 1 - 2 } $\begin{array}{l}\text { X4 } \\
\text { (Loyalitas Merek) }\end{array}$ & 2,996 &, 004 \\
\hline
\end{tabular}

Sumber : Diolah, 2018

(1) Variabel kesadaran merek Hasil ini memperlihatkan bahwa variabel kesadaran merek secara parsial berpengaruh signifikan terhadap kepercayaan 
merek.

(2) Variabel Kualitas yang dirasakan

Hasil ini memperlihatkan bahwa variabel Kualitas yang dirasakan secara parsial berpengaruh signifikan terhadap Kepercayaan Merek.

(3) Variabel Asosiasi Merek

Hasil ini memperlihatkan bahwa variabel asosiasi Merek secara parsial berpengaruh signifikan terhadap Kepercayaan Merek.

(4) Variabel Loyalitas Merek

Hasil ini memperlihatkan bahwa variabel Loyalitas Merek secara parsial berpengaruh signifikan terhadap Kesadaran Merek.

Hipotesis Pengaruh kesadaran merek (X1), kualitas yang dirasakan (X2) asosiasi merek (X3), Loyalitas merek (X4) terhadap variabel Keputusan Pembelian ( $Y$ ). adapun besarnnya nilai masing-masing berpengaruh dari variabel bebas terhadap variabel terikat dapat diketahui pada tabel berikut:

Tabel 4.20

Hasil Pengujian Hipotesis t

Pengaruh kesadaran merek (X1), kualitas yang dirasakan (X2) asosiasi merek (X3) terhadap variabel Keputusan Pembelian (Y)

\begin{tabular}{|l|l|l|l|}
\hline Variabel & $\mathbf{t}$ hitung & $\mathbf{t}$ tabel & Sig. \\
\hline $\begin{array}{l}\text { X1 } \\
\text { (kesadaran Merek) }\end{array}$ & 2,101 & \multirow{2}{*}{2,001} &, 040 \\
\cline { 1 - 2 } $\begin{array}{l}\text { X2 } \\
\text { (Kualitas yang dirasakan) }\end{array}$ & 2,453 &, 017 \\
\cline { 1 - 2 } $\begin{array}{l}\text { X3 } \\
\text { (Asosiasi Merek) }\end{array}$ & 2,902 &, 005 \\
\cline { 1 - 2 } $\begin{array}{l}\text { X4 } \\
\text { (Loyalitas Merek) }\end{array}$ & 2,307 &, 025 \\
\hline
\end{tabular}

Sumber : Diolah, 2018

(1) Variabel Kesadaran Merek

Hasil ini memperlihatkan bahwa variabel kesadaran merek secara parsial berpengaruh signifikan terhadap keputusan pembelian.

(2) Variabel Kualitas yang dirasakan

Hasil ini memperlihatkan bahwa variabel Kualitas yang dirasakan secara parsial berpengaruh signifikan terhadap Keputusan Pembelian.

(3) Variabel Asosiasi Merek 
Hasil ini memperlihatkan bahwa variabel asosiasi Merek secara parsial berpengaruh signifikan terhadap Kesadaran Merek.

(4) Variabel Loyalitas Merek

Hasil ini memperlihatkan bahwa variabel Loyalitas Merek secara parsial berpengaruh signifikan terhadap Keputusan Pembelian (Y).

Kepercayaan Merek (Z) terhadap Keputusan Pembelian (Y) Untuk mengetahui besarnya pengaruh dari Kepercayaan Merek (Z) terhadap Keputusan Pembelian $(Y)$ dapat dilihat pada tabel sebagai berikut:

Tabel 4.21

Pengaruh Kepercayaan Merek (Z) terhadap Keputusan Pembelian (Y)

\begin{tabular}{|l|l|l|l|}
\hline Variabel & t hitung & t tabel & Sig. \\
\hline $\begin{array}{l}\text { Z } \\
\text { (kepercayaan Merek) }\end{array}$ & 3,603 & 2,001 &, 001 \\
\hline
\end{tabular}

Sumber Diolah, 2018

(1) Variabel Kepercayaan Merek

Hasil ini memperlihatkan bahwa variabel Kepercayaan Merek (Z) secara parsial berpengaruh signifikan terhadap Keputusan Pembelian $(Y)$

Hipotesis kesadaran merek (X1), kualitas yang dirasakan (X2) asosiasi merek (X3) Loyalitas Merek (X4) terhadap variable Keputusan Pebelian (Y) melalui variabel Kepercayaan Merek (Z). Adapun besarnnya nilai masing-masing berpengaruh dari variabel bebas terhadap variabel terikat melalui variabel kepercayaan merek dapat diketahui pada tabel berikut:

Tabel 4.22

Hasil Pengujian Hipotesis $\mathbf{t}$

Pengaruh tidak langsung kesadaran merek (X1), kualitas yang dirasakan (X2) asosiasi merek (X3) Loyalitas Merek (X4) terhadap variabel Kepercayaan Merek (Z)

\begin{tabular}{|l|l|l|l|}
\hline Variabel & t hitung & t tabel & Sig. \\
\hline $\begin{array}{l}\text { X1 } \\
\text { (kesadaran Merek) }\end{array}$ & 2,646 & &, 010 \\
\cline { 1 - 2 } $\begin{array}{l}\text { X2 } \\
\text { (Kualitas yang dirasakan) }\end{array}$ & 2,039 & 2,001 &, 046 \\
\cline { 1 - 2 } $\begin{array}{l}\text { X3 } \\
\text { (Asosiasi Merek) }\end{array}$ & 2,091 &, 041 \\
\cline { 1 - 2 } $\begin{array}{l}\text { X4 } \\
\text { (Loyalitas Merek) }\end{array}$ & 2,305 &, 025 \\
\cline { 2 - 3 }
\end{tabular}

Sumber : Diolah, 2018 
(5) Variabel kesadaran merek

Hasil ini memperlihatkan bahwa variabel kesadaran merek secara parsial berpengaruh signifikan terhadap Keputusan Pembelian (Y) melalui kepercayaan merek.

(6) Variabel Kualitas yang dirasakan

Hasil ini memperlihatkan bahwa variabel Kualitas yang dirasakan secara parsial berpengaruh signifikan terhadap Keputusan Pembelian (Y) melalui Kepercayaan Merek.

(7) Variabel Asosiasi Merek Hasil ini memperlihatkan bahwa variabel asosiasi Merek secara parsial berpengaruh signifikan terhadap Keputusan Pembelian (Y) melalui Kepercayaan Merek.

(8) Variabel Loyalitas Merek

Hasil ini memperlihatkan bahwa variabel Loyalitas Merek secara parsial berpengaruh signifikan terhadap Keputusan Pembelian (Y) melalui Kesadaran Merek.

Berikut ini disajikan diagram path berdasarkan hasil analisis yang telah dilakukan:

\section{Gambar 4.2}

\section{Diagram Jalur Jalur}

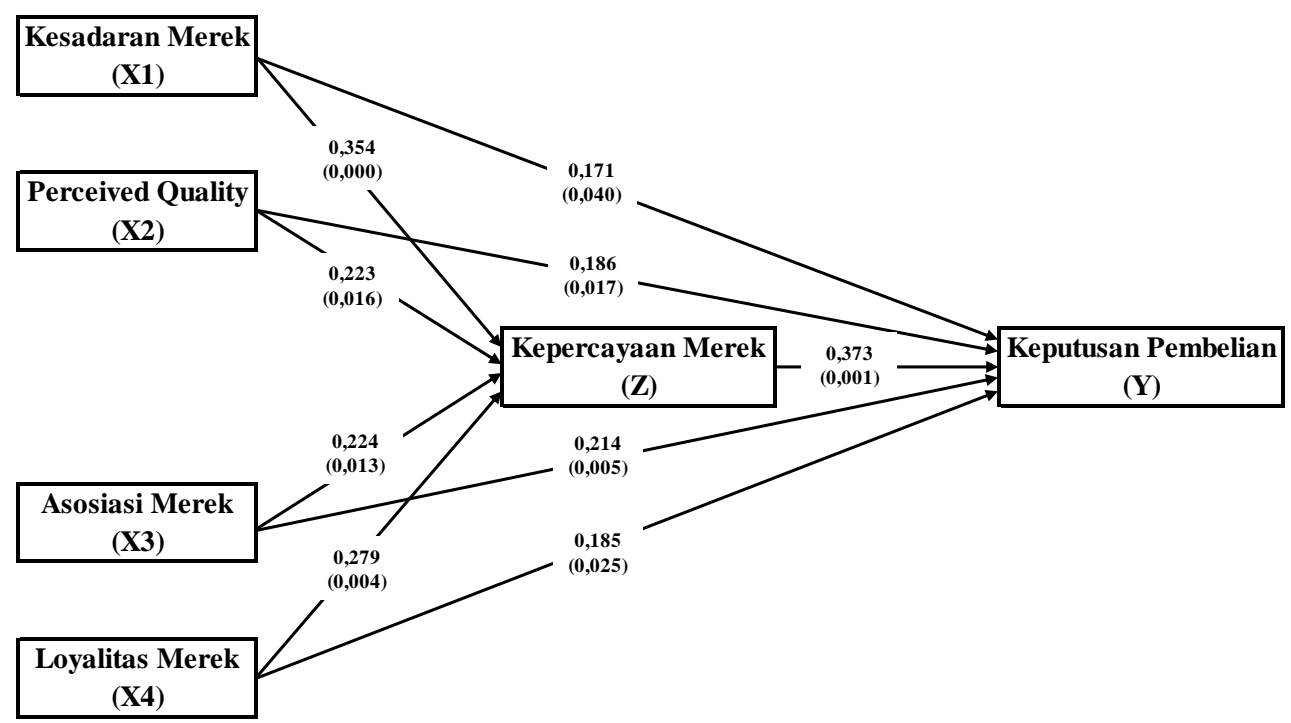

Besar nilai koefisien determinasi berkisar antara 0\% hingga $100 \%$, di mana semakin tinggi koefisien determinasi maka semakin baik pula model dalam menjelaskan data yang digunakan.

$$
R_{m}{ }^{2}=1-[(1-0,638) \times(1-0,771)]=0,917
$$

Koefisien determinasi total yang didapatkan berdasarkan hasil perhitungan model path adalah sebesar 0,917 yang menunjukkan bahwa model path yang digunakan dapat menjelaskan sebesar $91,7 \%$ data yangdigunakan dalam penelitian. 


\section{PEMBAHASAN}

Secara parsial variabel Kesadaran Merek (X1), Kualitas yang dirasakan (X2), Asosiasi Merek (X3), Loyalitas Merek (X4), Kepercayaan Merek $(Z)$ berpengaruh secara signifikan terhadap variabel Keputusan Pembelian (Y). Hal ini dapat dilihat pada tabel koefisien melalui pengujian hipotesis kemudian dibandingkan dengan t-tabel. Adapun persamaan jalur yang terbentuk yaitu :

\section{$Y=0,171 X 1+0,186 X 2+0,214 X 3+0,185 X 4+0,373 Z$}

Maka hasil dari tiap-tiap variabel dapat diketahui variabel manakah yang berpengaruh terhadap Keputusan Pembeliaan sebagai berikut : Kofisien Jalur Kesadaran Merek (X1), Menghasilkan nilai Beta Pada variabel Kesadaran Merek Ke variabel Keputusan Pembelian sebesar 0,171 dengan P-value 0,040. Hasil penelitian ini menjelaskan bahwa Kesadaran Merek berpengaruh terhaadap Kepercayaan Merek. Hal ini sesuai dengan apa yang dikatakan Durianto (2004:6) Kesadaran Merek menggambarkan keberadaan merek dalam pikiran konsumen, yang dapat menjadi penentu dalam beberapa kategori dan biasanya mempunyai peranan utama dalam Brand Equity. Kesadaran Merek juga mempengaruhi tingkah laku karena Kesadaran Merek merupakan kunci pembuka untuk masuk kedalam elemen lainya.

Kofesien variabel Loyalitas Merek ke Keputusan Pembelian sebesar 0,185 dengan $P$-value 0,025 . Hasil penelitian ini menyatakan bahwa Kualitas yang dirasakan berpengaruh terhadap Keputusan Pembelian Canon. Hal ini berarti Kualitas yang dirasakan Canon dianggap baik oleh konsumen. Ini sesuai dengan apa yang dikatakan durianto dkk (2004:15) bahwa kualitas pada dimensi yang tidak berwujud seperti inovasi akan memberikan keuntungan. Hal ini mengimplikasikan bahwa merek tersebut akan memberikan sesuai yang diinginkan konsumen.

Berdasarkan penelitian terdahulu yang dilakukan oleh Barus (2015) mengatakan bahwa Kualitas yang dirasakan berpengaruh terhadap Keputusan Pembelian. Hal ini sama dengan hasil penelitian sekarang yang menyatakan bahwa Kualitas yang dirasakan berpengaruh terhadap keputusan pembelian Canon. Kualitas yang dirasakan mempengaruhi rasa percaya diri pelanggan atas keputusan pembelian melalui keunikan atribut, karena menciptakan alasan yag kuat (reason to buy) bagi pelanggan untuk membeli yang dinilai mampu memenuhi (desired benefits) yang diinginkan pelanggan (Astuti dan Cahyadi, 2007).

Berdasarkan penelitian yang dilakukan dapat diketahui bahwa beberapa bentuk kualitas yang dirasakan yang ditunjukkan oleh responden meliputi: responden beranggapan bahwa kamera Canon merupakan kamera yang cara pengoperasiannya sangat mudah, tidak mudah rusak dan kamera yang mempunyai kualitas yang dapat diandalkan.

Kofisien variabel Asosiasi Merek ke Keputusan Pembelian sebesar 0,214 dengan P-value 0,005. Hasil penelitian ini menyatakan bahwa Asosiasi Merek berpengaruh terhadap Keputusan Pembelian Canon. Hal ini menunjukan bahwa logo atau symbol kamera Canon bisa diterima oleh masyarakat, kemudian sudah menjadi merek yang terkenal dan mudah dijumpai dimana-mana hal ini sesuai dengan yang dikatakan durianto dkk 
(2004) Asosiasi Merek adalah sebuah identitas yang menjadi penentu diferensiasi dan akan menjadi faktor penentu yang penting jika merek yang kita miliki mirip dalam hal atribut dengan merek lain. Berdasarkan penelitian terdahulu yang dilakukan oleh Kurniawan (2010) menyatakan bahwa asosiasi merek berpengaruh positif dan signifikan terhadap keputusan pembelian. Hal ini sama dengan hasil penelitian sekarang yang menyatakan bahwa Asosiasi Merek berpengaruh terhadap Keputusan Pembelian Canon.

Adapun bentuk dari Asosiasi Merek yang ditunjukkan oleh responden yaitu responden menganggap bahwa kamera Canon memiliki desain yang bagus, fitur yang canggih dan responden menganggap bahwa kamera Canon merupakan kamera yang memberikan manfaat bagi seorang fotografer.

Kofisien variabel Kepercayaan Merek ke Keputusan Pembelian sebesar 0,373 dengan P-value 0,00. Hasil penelitian ini menyatakan bahwa Loyalitas Merek berpengaruh terhadap Keputusan Pembelian Canon. Hal ini berarti terdapat beberapa hal yang menyebabkan konsumen loyal terhadap merek Canon. Sesuai dengan apa yang dikatakan durianto dkk (2004:15) kepuasan adalah pengukuran secara langsung bagimana konsumen tetap loyal kepada suatu produk. Berdasarkan penelitian terdahulu yang dilakukan oleh Wijaya (2011) dan Barus (2015) menyatakan bahwa Loyalitas Merek berpengaruh terhadap Keputusan Pembelian. Hal ini sama dengan hasil penelitian sekarang bahwa Loyalitas Merek berpengaruh terhadap Keputusan Pembelian Canon.

Tingkat loyalitas merek yang tinggi terhadap merek dapat diciptakan rasa percaya diri yang besar pada pelanggan saat pengambilan keputusan pembelian. Hal itu karena pelanggan merasa memiliki ikatan dengan merek sehingga pelanggan memiliki keyakinan yang besar bahwa keputusannya membeli merek tersebut adalah keputusan yang tepat.

Kofisien variabel Kepercayaan Merek ke Keputusan Pembelian sebesar 0,373 dengan $P$-value 0,001. Hasil penelitian ini menyatakan bahwa Kepercayaan Merek berpengaruh terhadap Keputusan Pembelian kamera Canon. Hal ini berarti terdapat beberapa hal yang menyebabkan konsumen percaya terhadap merek Canon. Sesuai dengan apa yang dikatakan Sari dan Widowati (2014) bahwa Kepercayaan Merek (Brand Trust) adalah kesediaan konsumen untuk mempercayai suatu merek dengan segala resikonya karena adanya harapan dibenak mereka bahwa merek tersebut akan memberikan hasil yang positif terhadap konsumen sehingga akan menimbulkan kesetiaan terhadap merek.

Kepercayaan Merek merupakan suatu bentuk sikap yang menunjukan perasaan suka dan tetap bertahan menggunakan suatu produk. Pada dasarnya kepercayaan akan timbul apabila produk yang dibeli oleh seorang konsumen mampu memberikan manfaat atau nilai yang diinginkan konsumen pada suatu produk. Berdasarkan penelitian terdahulu yang dilakukan oleh Nur awalludin dan sekar jingga citra menyatakan bahwa loyalitas merek berpengaruh terhadap keputusan pembelian. 


\section{SIMPULAN DAN SARAN}

Bersadarkan hasil penelitian dan pembahasan yang telah dilakukan maka dapat disimpulkan bahwa:

a. Variabel Kesadaran merek (X1), Kualitas yang dirasakan (X2), Asosiasi merek (X3), dan Loyalitas merek (X4) berpengaruh terhadap variabel Kepercayaan merek (Z). Dan variabel yang paling dominan mempengaruhi Kepercayaan merek adalah variabel Kesadaran merek.

b. Variabel Kesadaran merk (X1), Kualitas yang dirasakan (X2), Asosiasi merek (X3), dan Loyalitas merek (X4) berpengaruh signifikan terhadap variabel Keputusan Pembelian (Y). Dan variabel yang paling dominan mempengaruhi Keputusan pembelian adalah variabel Asosiasi merek merek.

c. Variabel Kepercayaan merek (Z) berpengaruh terhadap Keputusan Pembelian kamera Canon.

d. Berdasarkan Keputusan pembelian kamera Canon pada komunitas fotografi di Kota Malang terbukti di dominasi oleh variabel Kepercayaan merek.

\section{DAFTAR PUSTAKA}

A Aaker, David A. (2008) Manajemen Ekuitas merek. Jakarta: Mitra Utama Alma, Buchari. (2004). Manajemen Pemasaran dan Pemasaran Jasa. Cetakan

Keenam. Alfabeta. Bandung.

Arianis, Chan. (2010). Pengaruh Ekuitas Merek Terhadap Keputusan Pembelian

Konsumen (Study Kasus Bank Muamalat Indonesia Cabang Bandung). Jurnal Administrasi Bisnis. Vol 6 . No. 1. Hal $34-58$. Bandung.

Barus (2015) Pengaruh Ekuitas Merek Terhadap Proses Keputusan Pembelian

smartphone blackberry (Studi pada Mahasiswa Program S1 Jurusan Administrasi Bisnis Fakultas IImu Sosial dan IImu Politik). Jurusan Administrasi Bisnis, Fakultas IImu Sosial dan IImu Politik, Universitas Diponegoro.

Boy, Oon M S Pane dan Endang Sulistya Rini. (2011). Pengaruh Brand Equity

Flasdisk Merek Kingston Terhadap Keputusan Pembelian Pada Mahasiswa Amik Mbp Medan.

Cooper, Donald R. 2000. Metode Penelitian Bisnis. Edisi ke-5, Jilid 2. Erlangga :

Jakarta.

Chan, Arianis (2013). Pengaruh Ekuitas Merek Terhadap Proses Keputusan

Pembelian Konsumen : Studi Kasus Bank Muamalat Indonesia

Cabang Bandung.Jurnal Universitas Padjadjaran, Bandung. Hanin, Amira. 
Chan, Arianis (2013). Pengaruh Ekuitas Merek Terhadap Proses Keputusan

Pembelian Konsumen : Studi Kasus Bank Muamalat Indonesia Cabang Bandung.Jurnal Universitas Padjadjaran, Bandung. Hanin, Amira.

Dharmayana1, Rahanatha2 2017. Pengaruh brand equity, brand trust, brand

preference, dan kepuasan konsumen terhadap niat beli kembali. EJurnal Manajemen Unud, Vol. 6, No. 4, 2017: 2018-2046 ISSN : 2302-8912

Darmadi Durianto, Sugiarto, Tony Sitinjak. 2001. "Strategi Menaklukkan Pasar

Melalui Riset Ekuitas dan Perilaku Merek." Jakarta : Gramedia.

Durianto, Darmadi, Sugiarto dan Toni Sitinjak (2001). Strategi Menaklukkan Pasar

Melalui Riset Ekuitas dan Perilaku Merek. Jakarta: Gramedia Pustaka Utama.

Fauziyah "Pengaruh brand trust dan brand equity terhadap loyalitas konsumen pada

produk kosmetik wardah (Survey Konsumen Pada PT. Paragon Technology And Innovation Cabang Pekanbaru)" JOM FISIP Vol. 3 No. 2 - Oktober 2016

Ghanimata, Fifyanita. (2012). Analisis Pengaruh Harga, Kualitas Produk, dan

Lokasi Terhadap Keputusan Pembelian (Studi pada Pembeli Produk Bandeng Juwana Elrina Semarang). 